\title{
Yabancılara Türkçe Öğretiminde Yardımcı Kaynaklardan Yararlanma: Türkçenin Sesi Yunus Emre Örneği
}

\author{
The Use of Supplementary Resources in Teaching Turkish to Foreigners: The Case \\ of Voice of Turkish Yunus Emre
}

\author{
Öğr. Gör. Dr. Önder ÇANGAL (iD) 1
}

\begin{abstract}
$\ddot{\mathbf{O} z}$
Yabancilara Türkçe öğretiminde öğrencilerin dinleme, konuşma, okuma ve yazma becerilerinin geliştirilmesi; eş zamanlı olarak öğrencilere dil bilgisi yapılarının kazandırılması hedeflenmektedir. Öğreticiler süreci genellikle temel kaynaklar olan ders kitaplarından hareketle yürütmekte, kitapların yetersiz kaldığı durumlarda yardımcı kaynak ihtiyacı ortaya çıkmaktadır. Yunus Emre Enstitüsü, yabancılara Türkçe öğretiminde kullanılmak üzere hazırladığı yardımcı kaynaklarla öğreticilerin ve öğrenicilerin ihtiyaçlarını karşılamaya çalışmaktadır. Enstitü bünyesinde, Türkçe öğrenen yabancıların dil düzeylerine göre üç kitap hâlinde hazırlanan "Türkçenin Sesi Yunus Emre" seti de hem yardımcı okuma kitabı ihtiyacını gidermesi hem de Yunus Emre'nin hayatını konu edinmesi nedeniyle dikkat çekmektedir. Dil öğretiminde temel dil becerilerinin geliştirilmesi önemli olmakla birlikte öğretimin önemli boyutlarından biri de hedef dile ait kültürel değerlerin karşı tarafa tanıtılmasıdır. Temel, orta ve ileri düzey için hazırlanan "Türkçenin Sesi Yunus Emre" yardımcı okuma kitapları, hem yabancı öğrenicilerin hedef dilde okuma alışkanlığı kazanmalarına hem de Yunus Emre'nin hayatını öğrenmelerine yardım etmekte; hazırlanan etkinliklerle öğrenicilerin söz varlığı, okuma, dil bilgisi, yazma ve konuşma yeterliklerinin geliştirilmesi amaçlanmaktadır. Nitel araştırma yaklaşımına uygun olarak tasarlanan çalışmada araştırma verileri doküman analizi ile çözümlenmiştir. Bu çalışmada yabancılara Türkçe öğretiminde yardımcı kaynakların yerine ve dil öğretiminde kültür etkileşiminin önemine değinilmiş, Yunus Emre Enstitüsü tarafından 2020 yılında yayımlanan "Türkçenin Sesi Yunus Emre" yardımcı okuma kitapları incelenerek yabancılara Türkçe öğretiminde yardımcı kaynaklardan nasıl yararlanılabileceği ile ilgili önerilere yer verilmiştir.
\end{abstract}

Anahtar Kelimeler: Yabancılara Türkçe öğretimi, Türkçenin sesi Yunus Emre, yardımcı okuma kitabı

Makale Türü: Araştırma

\begin{abstract}
In teaching Turkish to foreigners, it is aimed to provide students with grammatical structures apart from developing students' reading, listening, speaking and writing skills. Instructors usually conduct the process based on the textbooks, which are the main resources, and when the books are insufficient, the need for supplementary resources arises. Yunus Emre Institute is trying to address the needs of teachers and learners with the supplementary resources which have been prepared to be used in teaching Turkish to foreigners. The "Voice of Turkish Yunus Emre" set, prepared by experts within the Institute, takes attention as supplementary reading books for foreigners learning Turkish. Although it is important to develop basic language skills in language teaching, one of the important dimensions of teaching is to introduce the cultural values of the target language to learners. In this respect, the "Voice of Turkish Yunus Emre" supplementary reading books, prepared according to levels, help foreign learners acquire the habit of reading in the target language, and learn about Yunus Emre's life and get to know him closely as well; with the activities, it aims to improve the vocabulary, reading, grammar, writing and speaking competencies of the learners. In the study, which was designed in accordance with the qualitative research approach, the research data were obtained by document analysis. In this study, the place of supplementary
\end{abstract}

\footnotetext{
${ }^{1}$ Gaziantep Üniversitesi, Türkçe Öğretimi Uygulama ve Araştırma Merkezi, ondercangal@hotmail.com
}

Atıf için (to cite): Çangal, Ö. (2021). Yabancılara Türkçe öğretiminde yardimci kaynaklardan yararlanma: Türkçenin Sesi Yunus Emre örneği. Afyon Kocatepe Üniversitesi Sosyal Bilimler Dergisi, 23(Yunus Emre ve Türkçe Özel Sayısı), 198-211. 
resources in teaching Turkish to foreigners and the importance of cultural interaction in language teaching were mentioned, and the "Voice of Turkish Yunus Emre" supplementary reading books published by Yunus Emre Institute in 2020 were examined and suggestions were given on how to benefit from supplementary resources in teaching Turkish to foreigners.

Keywords: Teaching Turkish to foreigners, voice of Turkish Yunus Emre, supplementary reading book

Paper Type: Research

\section{Giriş}

Dil öğretimi süreçleri; dört temel dil becerisi olarak da adlandırılan dinleme, konuşma, okuma ve yazma becerisinin geliştirilmesi üzerine planlanmakta, süreçte öğrenicilere düzeylerine uygun dil bilgisi yapılarının öğretilmesi amaçlanmaktadır. Öğretim süreçleri genellikle ders kitapları üzerinden kurgulanmakta, belirlenen ders saatini tamamlayan ve başar11ı olan öğreniciler bir üst düzeye geçmektedir.

Ders kitapları, yabancı dil olarak Türkçe öğretimi süreçlerinde en önemli başvuru kaynaklarıdır. Bununla birlikte öğrenme hedeflerinin gerçekleştirilmesinde ders kitapları tek başına yeterli değildir. Bu nedenle öğreticiler genellikle kendi öğrenci gruplarının özelliklerine uygun ders materyalleri hazırlamakta ve derslerinde kullanmaktadır. Özellikle söz varlığ geliştirme ve dil bilgisi yapılarını öğretme aşamalarında powerpoint vb. sunu araçları ile hazırlanan ders içerikleri öğrenmeyi kolaylaştırmakta ve öğrenilenlerin akılda kalıcıllı̆ı artmaktadır. Yine dil öğretiminde video, şarkı, film ve oyunlardan yararlanmak öğrenicilerin hem eğlenmesini hem de öğrenmesini sağlamaktadır.

Bireyler tarafindan hazırlanan ders materyallerinin yanı sira kurumlar tarafindan hazırlanan yardımcı kaynaklar da dil öğrenme hedeflerine ulaşmada önem arz etmektedir. Yabancılara Türkçe öğretimi alanında özellikle Yunus Emre Enstitüsünün hazırladığı kaynaklar önemli bir yer tutmaktadır. Enstitü, hazırladığ 1 kaynaklarda hedef kitlenin hem dil becerilerini geliştirmeyi hem de Türk kültürüne yönelik farkındalıklarını artırmayı amaçlamaktadır.

Dil öğretimi, aynı zamanda kültür öğretimi demektir. Nitekim öğreniciler yeni bir dil öğrenirken hedef dile ait kültürel değerleri de tanımakta, bu sayede kendi kültürleri ile hedef dilin kültürel değerleri arasında bağ kurma fırsatı bulmaktadır. Bu tür paylaşımlar dil öğrenme süreçlerini eğlenceli kılmakta, öğrenicilerin motivasyonlarını yükseltmektedir. $\mathrm{Bu}$ nedenle yabancılara Türkçe öğretiminde kullanılmak üzere hazırlanacak ders materyallerinde gerek Türk kültüründe yer etmiş önemli şahsiyetlere gerekse onların eserlerine yer verilmesi önemli bir husus olarak dikkat çekmektedir.

Yunus Emre, tasavvuf ve halk şiirinin öncüsü olan önemli bir şahsiyettir. Açık ve anlaşılır bir dille Türkçe olarak yazdığı şiirleri bugün bile kolaylıkla anlaşılmakta ve ilgi görmektedir. Bu nedenle yabancılara Türkçe öğretimi amacıyla hazırlanacak olan yardımcı kaynaklarda Yunus Emre'ye yer verilmesi, onun eserlerinden hareketle içeriklerin hazırlanması öğrenicilere zengin öğrenme ortamları sunacaktır. Bu bağlamda Yunus Emre Enstitüsü tarafından yabancılara Türkçe öğretimi süreçlerinde kullanılmak üzere hazırlanan ve Yunus Emre'nin hayatının bir kurgu içerisinde verildiği "Türkçenin Sesi Yunus Emre" yardımcı okuma kitapları incelenmesi gereken önemli bir kaynak olarak ortaya çıkmaktadır.

"Türkçenin Sesi Yunus Emre" yardımcı okuma kitapları, hem dil öğretim süreçlerine katk1 sağlama hem de Türk kültürüne ait önemli bir değer olan Yunus Emre'yi yabancılara tanıtma amacı taşımaktadır. Bu nedenle çalışmada yabancılara Türkçe öğretiminde yardımcı kaynakların yerine ve dil öğretiminde kültürel etkileşimin önemine değinilmiş, "Türkçenin Sesi Yunus Emre" yardımcı okuma kitapları incelenerek yabancılara Türkçe öğretiminde yardımc1 kaynaklardan nasıl yararlanılabileceği ile ilgili önerilere yer verilmiştir. 


\section{Yabancılara Türkçe Öğretiminde Yardımcı Kaynaklardan Yararlanma}

Dil öğretiminde yardımcı kaynaklardan yararlanmak, dersi sıradanlıktan kurtarmakta ve hedef kitlenin öğrenme motivasyonunu yükseltmektedir. $\mathrm{Bu}$ nedenle yabancılara Türkçe öğretenler kendi öğrenici gruplarının özelliklerine uygun yardımcı materyaller hazırlamakta ve bu materyalleri derslerinde kullanmaktadır. Özellikle Powerpoint, Prezi, Canva gibi sunu araçları ile hazırlanan materyaller temel düzeydeki söz varlığını geliştirme ve dil bilgisi yapılarını öğretme sürecinde oldukça yararlı olmaktadır.

Yabancılara Türkçe öğretimi süreçlerinde kullanılmak üzere kurumlar tarafından hazırlanan yardımcı kaynaklar da bulunmaktadır. Türkiye Maarif Vakfı ve Yunus Emre Enstitüsü yabancılara Türkçe öğretimi alanı için kaynak hazırlayan başlıca kurumlar olarak dikkat çekmektedir. Türkiye Maarif Vakfı, hazırladığı "Türkçenin Yabancı Dil Olarak Öğretimi Programı" ile çok önemli bir eksikliği gidermiş; program, Millî Eğitim Bakanlığı Talim ve Terbiye Kurulu Başkanlığının onayı ile yabancılara Türkçe öğretimi alanı için hazırlanmış ilk resmî program olarak kayıtlara geçmiştir. Vakıf yurt dışındaki eğitim kurumlarında kullanılmak üzere çeşitli ders kitapları da hazırlamaktadır.

Yunus Emre Enstitüsü hazırladığı yardımcı kaynaklarla hem yabancılara Türkçe öğretenlerin hem de yabancı dil olarak Türkçe öğrenenlerin materyal ihtiyacını karşılamaktadır. Enstitü tarafından hazırlanan yardımcı kaynaklar şunlardır:

- Kelime Öğretimi Afişleri

- Resimlerle Kelime Öğreniyorum

- Yedi İklim Türkçe Konuşma ve Yazma Kitabı

- Yedi İklim Türkçe Damak Tadı

- Yedi İklim Türkçe Video Etkinlik Kitabı

- Yabancilar için Türkçe Konuşma Kılavuzu

- Yedi İklim Türkçe Zenginleştirilmiş Kitap (Z-Kitap)

- Çocuk Hikâyeleri Dizisi

- Anadolu Hikâyeleri

- Dede Korkut Hikâyeleri

- Türkçenin Sesi Yunus Emre Hikâyeleri

Enstitü hazırladığı yardımcı kaynaklarda görselliği ön plana çıkarmakta, çizim ve fotoğraflarda kitapların temasına uygun, yüksek kaliteli görseller kullanmaktadır. Özellikle söz varlığ1 kazandırma amacıyla hazırlanan "Kelime Öğretimi Afişleri” ile "Resimlerle Kelime Öğreniyorum" çalışmalarında kelimeler öğrenicilere temalar altında kaliteli çizimlerle verilmekte, öğrenicilerin görsel zekâlarına hitap edilerek öğrenmenin kolaylaşması amaçlanmaktadır. Hazırlanan diğer kaynaklarda da metinler görsellerle zenginleştirilmiş; "Yedi İklim Türkçe Konuşma ve Yazma Kitabı", "Yedi İklim Türkçe Damak Tadı", "Yedi İklim Türkçe Video Etkinlik Kitabı" ve "Yabancılar için Türkçe Konuşma Kılavuzu" ile öğrenicilere önce girdi sağlanması, daha sonra bu girdilerden hareketle öğrenicilerin üretici becerilerinin geliştirilmesi amaçlanmıştır.

Enstitü tarafından hazırlanan yardımcı okuma kitapları da yabancılara Türkçe öğretiminde kullanılabilecek önemli kaynaklar olarak dikkat çekmektedir. Yunus Emre Enstitüsü hazırladığı "Çocuk Hikâyeleri Dizisi", “Anadolu Hikâyeleri", "Dede Korkut Hikâyeleri" ve "Türkçenin Sesi Yunus Emre" yardımc1 okuma kitapları ile Türkçe öğrenen 
yabancıların hem okuma becerilerini geliştirmeyi hem de ders dışı süreçlerde öğrenicilerin dile maruz kalmalarını sağlamayı amaçlamaktadır.

"Çocuk Hikâyeleri Dizisi" toplam on iki hikâye kitabından oluşmaktadır. Hikâyelerin 6’s1 A1, 6's1 A2 düzeyi için hazırlanmıştır. Kitapların hedef kitlesi 10-15 yaş arası Türkçe öğrenen yabanc1 çocuklardır. Her kitapta önce hikâye metnine, sonra metne yönelik anlama sorularına ve dil yapıları ile ilgili etkinliklere yer verilmiş, hikâyeler çocukların yaşlarına uygun çizimlerle desteklenmiştir.

"Anadolu Hikâyeleri"; A1-A2 düzeyi için yazılmış "Lâleye Sor", "Kırmızı Ayakkabılar", "Bir Bardak Çay", "Bayramlık" ve "Yılkı" adlı beş hikâye kitabından oluşmaktadır. Her kitapta önce hikâyeye sonra etkinlikler ve cevaplar bölümlerine yer verilmiştir. Kitaplardaki etkinlikler kelime, anlama, dil bilgisi, yazma ve konuşma bölümlerinden oluşmaktadır. Yetişkinler için hazırlanan hikâye kitapları ile hem öğrenicilerin yardımcı okuma kitabı ihtiyacının karşılanması hem de Anadolu kültürünün öğrenicilere tanıtılması amaçlanmaktadır.

Türkçeyi yabanc1 dil olarak öğrenen yetişkin öğrenicilerin yardımcı okuma kitabı ihtiyacını karşılamak üzere hazırlanan "Dede Korkut Hikâyeleri" ve "Türkçenin Sesi Yunus Emre" setleri Türk kültürünün sembol isimlerinden Dede Korkut'un hikâyelerini ve Yunus Emre'nin hayatını içermesi nedeniyle önem arz etmektedir. Bu setlerde de önce hikâye arkasından da etkinlikler bölümü verilerek öğrenicilerin hem eğlenmesi hem de dil becerilerini geliştirmesi hedeflenmektedir.

Yunus Emre Enstitüsü dışında farklı kurumlar tarafindan da yabancılara Türkçe öğretiminde kullanılacak yardımcı kaynaklar hazırlanmıştır. Bu kaynaklardan bazıları şunlardır:

- Yabancı Dilim Türkçe (Dilmer Yayınları)

- Türkçe Okuyorum (Dilmer Yayınları)

- Oyun ve Etkinliklerle Yabancılara Türkçe Öğretimi (YDS Publishing)

- Filmlerle Yabancılara Türkçe Öğretimi (Nobel Akademik Yayıncılık)

- Yabancı Uyruklular için Şarkılarla Türkçe Öğretimi (Sakarya Üniversitesi)

- Yabancı Dil Olarak Türkçe Öğretimi Hikâye Seti (Kültür ve Turizm Bakanlığı GENÇDES Projesi)

- Yabanc1lar için Türkçe Okuma Kitabı (Delta Kültür-Eğitim)

- Yeni Dünya Yabancılar için Türkçe Okuma Kitabı (Mevsimler Kitap)

- Yabancılar için Türkçe Okuma Kitabı - Yenisey (Palet Yayınları)

- Yabancılar için Türkçe Okuma Kitabı Serisi (Erdem Yayınları)

- Yabancilar için Türkçe Okuma Metinleri (Cinius)

- Yabancılar için Türkçe Konuşma Kılavuzu (Cinius)

- Türkçe Okuyalım Yazalım - Yabancılar için Türkçe (Papatya Bilim)

- Yabancılar için Arapça Açıklamalı Türkçe Okuma Metinleri (Hiperlink)

Hazırlanan kaynaklar incelendiğinde okuma becerisinin geliştirilmesine yönelik çalışmaların yoğunlukta olduğu, yazma ve konuşma becerilerinin geliştirilmesi için de bazı kaynakların hazırlandığı görülmektedir. Yine listede oyun, etkinlik, şarkı ve videolar ile yabancılara Türkçe öğretimine yönelik kaynaklar da bulunmaktadır. 
Yabancılara Türkçe öğretiminde yardımcı kaynak kullanımı öğretim süreçlerini desteklemekte, sınıf dışı ortamlarda da öğrenicileri hedef dile maruz bırakmakta, öğrenicilerin dili eğlenerek öğrenmesini sağlamaktadır. Bu nedenle alanda çalışan öğreticilerin hazırlanan yardımc kaynakları incelemesi ve uygun gördüklerini kendi gruplarında kullanması gerekmektedir. Yardımcı kaynakların seçiminde hedef kitlenin yaş, dil öğrenme amacı, dil düzeyi, ülkesi, Türkiye'de bulunma süresi gibi değişkenler dikkate alınmalı; öğrenicilerin kültürel, millî ve dinî hassasiyetlerine dikkat edilmeli; öğrenme hedeflerine hizmet edecek kaynaklar seçilerek derslerde kullanılmalıdır.

\section{Yabancılara Türkçe Öğretiminde Kültürel Etkileşimin Önemi}

Dil öğretiminde kültürel etkileşim, üzerinde durulması gereken önemli bir meseledir. Türkçeyi yabancı dil olarak öğrenen öğreniciler; teknoloji sayesinde Türkiye ve Türk kültürüne ilişkin verilere ulaşmakta, farklı kaynaklardan edindikleri bilgileri ders ortamında öğreticiye soru olarak yöneltmekte ve merak ettikleri hakkında öğreticinin kendilerini bilgilendirmesini beklemektedir.

Türk dizileri bugün dünyanın dört bir yanında ilgi görmekte, yabancılar dizilerden hareketle Türk toplumunu tanıma ve Türk dilini öğrenme gayreti içerisine girmektedir. İzledikleri dizilerde Türk kültürüne ait gelenek, görenek ve unsurlara rastlayan öğreniciler gördüklerinin kendi kültüründeki karşılıklarına yoğunlaşmakta, benzerlik ve farklılıkları sınıf ortamında dile getirmektedir. $\mathrm{Bu}$ nedenle yabancılara Türkçe öğreteceklerin bu konuda farkındalığının yüksek olması, öğrenicilere Türk kültürünü doğru şekilde tanıtması, hareket ve davranışlarıyla öğrenicilerine iyi bir örnek olması gerekmektedir. Bu aşamada alanda çalışacak öğreticilerin Türk kültürünü iyi bilen, ona uygun hareket eden, bildiklerini yeri geldikçe derslerinde kullanan ve öğrenicilerin kültürlerine saygı duyan bireyler olarak yetiştirilmesinin önemi ortaya çıkmaktadır.

Yabancılara Türkçe öğretmenliği lisans programları olmadığı için alanın öğretici ihtiyac1 üniversitelerin Türkçe öğretmenliği, Türk dili ve edebiyatı öğretmenliği, Türk dili ve edebiyatı bölümü, çağdaş Türk lehçeleri gibi bölümlerinden karşılanmaktadır. Bu bölümlerden mezun olanlar daha sonra üniversitelerin düzenlediği "Yabancilara Türkçe Öğretimi Sertifika Programları"na katılmakta, gerek teorik anlamda gerekse uygulama anlamında kendisini geliştirmeye çalışmaktadır. Alanda çalışacak kişilerin entelektüel bireyler olmaları ve genel kültür düzeylerinin yüksek olması önemli olmakla birlikte bu kişilerin sahip oldukları kültürel birikimlerini ders ortamlarında bağlamına uygun bir şekilde kullanabilmeleri de önem arz etmektedir. Kişilerin bu yetkinliklerini "Yabancılara Türkçe Öğretiminde Kültürel Etkileșimin Sağlanması"na yönelik derslerle veya programlarla kazanmaları ve kendilerini geliştirmeleri mümkündür.

Bursa Uludağ Üniversitesi Eğitim Bilimleri Enstitüsü Yabanc1 Dil Olarak Türkçe Öğretimi Yüksek Lisans Programı kapsamında "Türkçeyi yabancı dil olarak öğretecek öğretmen adaylarına edebî metinleri ve edebî metinlerdeki Türk kültürüne ait unsurları öğrencilerine aktarma konusunda yeterli düzeyde kuramsal bilgi ve deneyim ..." (Bursa Uludağ Üniversitesi, 2021) kazandırmak amacıyla "Türkçenin Yabancı Dil Olarak Öğretiminde Kültür Aktarımı" dersi verilmektedir. Benzer dersler farklı üniversitelerin lisans programlarında da bulunmaktadır. Fakat Türkçenin yabancı dil olarak öğretimi alanına öğretici yetiştiren bölümler özelinde tüm üniversitelerde "Yabancılara Türkçe Öğretiminde Türk Kültürü" derslerinin lisans programlarına girmesi ve standardın sağlanması gerekmektedir.

Türk Dil Kurumu ve Adnan Menderes Üniversitesi iş birliğiyle 15-16 Nisan 2019 tarihlerinde düzenlenen "Yabancılara Türkçe Öğretiminde Kültür Aktarımı Çalıştayı" bu bağlamda çok önemlidir. Alanda çalışan akademisyenler Çalıştay kapsamında meseleyi "kültür öğretimi ve amaçları", "kültürel içerikler", dil öğretim ortamları ve kültür çeşitliliği”, "kültürel içerikler ile dil düzeyleri arasındaki ilişkiler", "kültürlerarası iletişim" ve "kültürlerin karşılaşma alanı olarak dil öğretim ortamları" başlıkları altında ele almış ve yabancılara Türkçe 
öğretiminde kültürel etkileşime yönelik değerlendirmelerde bulunmuşlardır (Türk Dil Kurumu, 2019).

Yabancılara Türkçe öğretiminde kültürel etkileşim ile ilgili pek çok çalışma yapılmıştır (bk. Çangal, 2012; Kalfa, 2013; Okur ve Keskin, 2013; Elbir ve Aka, 2015; Alyılmaz ve Er, 2016; Memiş, 2016; İşcan, 2017; Yılmaz ve Akkaya, 2018; Moralı ve Göçer, 2019; Güleç ve Ömeroğlu, 2020). Yapılan çalışmalar yabancılara Türkçe öğretiminde kültürel etkileşimin sağlanmasının önemli olduğunu; öğreticilerin Türk kültürüne ait gelenek, görenek ve şahsiyetlere derslerinde yer vermesi gerektiğini; bunun bir dayatma şeklinde değil de mevcut değerleri karşı tarafa tanıtma şeklinde olmasının önemini, süreçte öğrenicilerin kültürel değerlerine hassasiyet gösterilmesi gerektiğini ortaya koymaktadır.

Yabancılara Türkçe öğretiminde kültür etkileşimin doğru şekilde sağlanması çok önemlidir. Bunun için bir yol haritasının çizilmesi ve durumun yalnızca öğreticilerin inisiyatifine bırakılmaması gerekmektedir. Çelik'in (2018, s. 180-182) yabancılara Türkçe öğretiminde kültürel etkileşimin sağlanmasına yönelik geliştirdiği öneriler şu şekildedir:

- Türk kültürünü tanıtıcı gezi müfredatları geliştirilmeli, üniversite TÖMER'lerinin bulundukları bölgeleri kapsayan kitapçıklar hazırlanmalıdır.

- Yabancı öğrencilerin Türk kültürüne uyumlarını hızlandırmak amacıyla kültür atlasları hazırlanmalıdır.

- Türk kültürünü yansıtan afişler hazırlanmalı, TÖMER binalarına ve sınıflarına asılmalıdır.

- Yabancılara Türkçe öğreteceklerin kültürel yetkinliklerini artırmaya yönelik dersler lisans, yüksek lisans ve doktora programlarına eklenmeli, kültürel değerlere yönelik farkındalığı yüksek öğreticiler yetiştirilmelidir.

- Türkiye'yi ve Türk kültürünü öğrenicilere anlatacak, onlara şehirle ilgili rehberlik yapabilecek uzmanlarla, sivil toplum kuruluşlarıyla ve topluma yön veren simalarla iş birliği yapılmalı; bu kişiler ile öğreniciler bir araya getirilmelidir.

- Kamu kurumları ve özel kurumlar ile irtibata geçilerek uluslararası öğrencilerin topluma ve Türk kültür yaşamına uyumlarını sağlamak amacıyla etkinlikler düzenlenmelidir.

- Türk kültürünü tanıtmada sosyal medya araçlarından etkin şekilde yararlanabilmeleri için TÖMER okutmanlarına sosyal medya kullanımı eğitimi verilmelidir.

- Öğreticiler kendi öğrenicilerinin kültürel değerleri hakkında farkındalığa sahip olmalı ve kendilerini bu doğrultuda geliştirmelidir.

Yabancılara Türkçe öğretimi derslerinde öğreticiler kültürel değerleri tanıtmada herhangi bir programı takip etmemekte, ders kitabındaki sırayla konuları öğrenicilere vermekte, yeri geldiğinde dersin konusundan hareketle kendi kültürel birikimini öğrenicileri ile paylaşmaktadır. Çelik (2018), doktora tezinde "yabancı dil olarak Türkçe öğretiminde kültürel etkileşim" meselesini öğretim programlarında, ders kitaplarında ve sınıflarda kültürel etkileşim olmak üzere üç başlikta ele almakta; Türkçe öğrenen yabancilara verilmesi gereken öncelikli Türk kültürü unsurları ile ilgili bir çerçeve çizmektedir. Çizilen çerçeve Türk dili ve kültürünün sistemli bir şekilde karşı tarafa verilmesi için önemli bir çalışmadır. Bununla birlikte Türkiye Maarif Vakfı Türkçenin Yabancı Dil Olarak Öğretimi Programından hareketle hazırlanacak ders kitaplarında da benzer çerçevelerin çizilmesi ve kültürel değerlerin A1'den C2'ye kadar sistemli bir şekilde öğrenicilere aktarılması gerekmektedir.

Yunus Emre Enstitüsü, Türk dilinin öğretimi çalışmalarının yanı sıra Türkiye'nin kültürel birikimini yurt dışında tanıtabilmek amacıyla pek çok faaliyet gerçekleştirmektedir. Enstitü, Türk geleneğinden esinlenilen faaliyetlerle modern dünyanın insanlarına ulaşmaya, onlara sürekli gelişen ve değişen Türk kültür birikimini sunmaya ve faaliyetleri yoluyla Türkiye'yi anlatmaya çalışmakta; Türkiye'nin kültürel ve bilimsel birikimini uluslararası alanda 
duyurmayı, başka ülkelerin tecrübesini de Türk topraklarına ulaştırmayı amaçlamaktadır (Yunus Emre Enstitüsü, 2017). Benzer şekilde Türkiye Maarif Vakfı ve Türkiye'deki üniversitelerin Türkçe Öğretimi Uygulama ve Araştırma Merkezleri de faaliyetler yürütmekte, Türkçe öğrenen yabancıların Türk kültürünü yakından tanımasını hedeflemektedir.

\section{Amaç}

Ders kitapları öğretim süreçlerinin yürütülmesinde tek başına yeterli olmamakta, öğreticiler süreçte yardımcı kaynaklara ihtiyaç duymaktadır. Öğreticiler tarafından hazırlanan ders materyallerini yardımcı kaynak kategorisine dâhil etmek mümkündür. Bununla birlikte kurumlar tarafından hazırlanacak yardımcı kaynaklara ve materyallere de yabancılara Türkçe öğretimi alanında ihtiyaç duyulmaktadır. Bu yönüyle Yunus Emre Enstitüsü tarafından hazırlanan yardımcı materyaller, hem öğreticiler hem de öğreniciler için önemli bir ihtiyacı karşılamaktadır.

Dil öğretiminin en önemli boyutlarından biri de hedef dile ait kültürel değerlerin öğrenicilere tanıtılmasıdır. Gerek kurumlar gerekse şahıslar temelinde hazırlanacak yardımcı kaynaklarda Türk kültürüne ait değerlerin ve şahısların doğru ve yeterli düzeyde tanıtılması çok önemlidir. Bu tür içerikler öğrenicilerin ilgisini çekmekte, Türk kültürüne ait değerleri tanıyan öğrenciler Türk kültürü ile kendi kültürleri arasında karşılaştırma yapma imkânı bulmaktadır.

Dil öğretiminde yardımcı kaynaklardan yararlanılması ve kültürel değerlerin öğrenicilere yeterli kadar tanıtılması gerekliliklerinden hareketle bu çalışmada "Türkçenin Sesi Yunus Emre" yardımcı okuma kitaplarının incelenmesi ve yabancılara Türkçe öğretiminde yardımcı kaynaklardan yararlanılması ile ilgili değerlendirmelerde bulunulması amaçlanmıştır.

\section{Yöntem}

Nitel araştırma yaklaşımına uygun olarak tasarlanan çalışmada araştırma verileri doküman analizi ile elde edilmiştir. Doküman incelemesi, bir araştırma problemi hakkında belirli zaman dilimi içerisinde üretilen dokümanlar ya da ilgili konuda birden fazla kaynak tarafından ve değişik aralıklarla üretilmiş dokümanların geniş bir zaman dilimine dayalı analizini olanaklı kılmaktadır (Yıldırım ve Şimşek, 2000, s.140-143). Çalışmada yabancılara Türkçe öğretiminde yardımcı kaynak kullanımı ve kültürel etkileşim meseleleri üzerinde durulmuş, "Türkçenin Sesi Yunus Emre" yardımcı okuma kitapları incelenmiş ve yabancılara Türkçe öğretiminde yardımcı kaynakların kullanımına yönelik önerilerde bulunulmuştur.

"Türkçenin Sesi Yunus Emre" seti hem yardımcı kaynak olması hem de Türk kültürünün sembol şahsiyetlerinden olan Yunus Emre'nin hayatını anlatması nedeniyle çalışmaya dâhil edilmiştir. Araştırmada anket, mülakat, odak grup görüşmesi, gözlem vb. teknikler kullanılmadığı için "Etik Kurul Onay Belgesi”" alınmamıştır. Araştırma kapsamında ele alınan "Türkçenin Sesi Yunus Emre" yardımcı okuma kitapları Yunus Emre Enstitüsü tarafından yayımlanmıştır. Söz konusu eserin çalışmada incelenebilmesi için Yunus Emre Enstitüsüne 15.05.2021 tarihinde dilekçe ile başvurulmuş, 28.05.2021 tarihli ve E-63048327605.01-037163 sayılı yazı ile Enstitüden araştırma izni alınmıştır.

\section{Bulgular}

\section{1. “Türkçenin Sesi Yunus Emre" Kitaplarının Biçimsel Görünüm, Bilimsel İçerik, Dil ve Anlatım Yönünden İncelenmesi}

Türkçenin Sesi Yunus Emre, "Türkçeyi yabancı dil olarak öğrenen yetişkinlerin yardımcı okuma kitabı ihtiyacına cevap vermek amacıyla hazırlanmıştır. Türkçenin edebî söyleyişini hikâye türünün unsurlarıyla, büyük Anadolu mutasavvıfı Yunus Emre'nin hayatı ve düşüncesiyle birleştirerek üç farklı düzeye uyarlanan bu kitap, yardımcı okuma materyallerinde ilkleri bünyesinde barındırmaktadır" (Yunus Emre Enstitüsü, 2020a). Set; temel (A1/A2), orta $(\mathrm{B} 1 / \mathrm{B} 2)$ ve ileri $(\mathrm{C} 1 / \mathrm{C} 2)$ düzey için hazırlanmış üç kitaptan oluşmaktadır. Kitapların ön ve arka kapakları ile iç sayfalarda kullanılan illüstrasyonlarda farklılık bulunmamaktadır. Bununla 
birlikte kitapların tasarımlarında temel düzey için yeşil, orta düzey için mavi ve ileri düzey için turuncu renklerinden yararlanılmıştır. Ön kapakta kitabın adı, düzeyi, buğday illüstrasyonu ve Yunus Emre Enstitüsünün logosu bulunmakta, arka kapakta ise "aşk"ın ne demek olduğunu açıklayan bir paragraf yer almaktadır. Kitapların ön kapakları şu şekildedir:

Şekil 1. Türkçenin Sesi Yunus Emre seti ön kapak görselleri

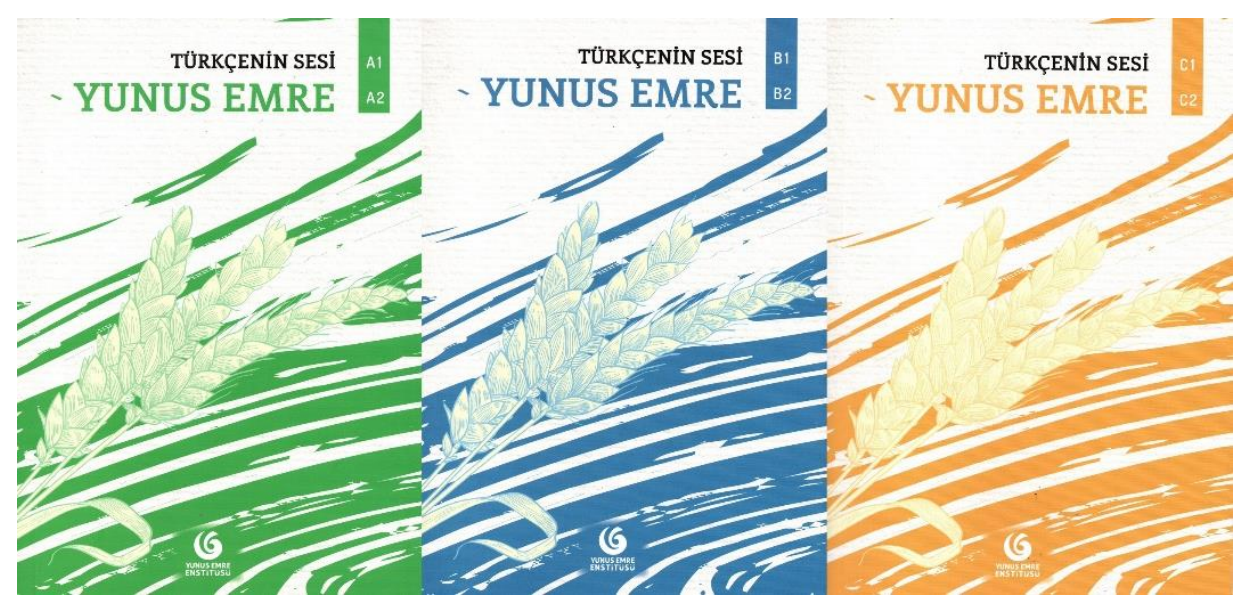

"İllüstrasyon, gerçekliğin veya hayal gücünün gelişen teknolojinin de katkılarıyla onu açıklayan, somutlaştıran kompozisyonların resimlendirilmesi anlamına gelir" (Acartürk, 2019, s. 8). Ön kapakta "buğday" illüstrasyonunun kullanılması tesadüfi bir durum değildir. Buğday illüstrasyonu ile Eskişehir'in Mihalıççık ilçesine bağlı Sarıköy'de çiftçilik yapan genç Yunus'un; önce Hacı Bektâş-1 Velî sonra Tapduk Emre ile tanıştığı ve Derviş Yunus olduğu yolculuğa çıkma sebebine bir gönderme yapılmaktadır. Zira genç Yunus bu yolculuğa toprağa ekecek tek bir buğday tohumunun bile kalmaması nedeniyle çıkmış, daha sonra ilahi aşkı bulma amacıyla yolu Tapduk Emre'nin dergâhına düşmüştür.

Kitapların arka kapaklarında yer alan ve "aşk"1 anlatan paragraflarda düzeylere göre birtakım uyarlamalar yapılmıştır. Arka kapakta yer alan paragraflar şu şekildedir:

Tablo 1. Türkçenin Sesi Yunus Emre seti arka kapakta yer alan paragraflar

\begin{tabular}{|c|c|c|}
\hline Temel (A1-A2) & Orta (B1-B2) & İleri (C1-C2) \\
\hline $\begin{array}{l}\text { Aşk "bağ"dır. İnsanla Tanrı } \\
\text { arasında bir bağ... İnsanla } \\
\text { insan arasında bir bağ... } \\
\text { İnsanla bütün canlilar } \\
\text { arasında bir bağ... İnsanla } \\
\text { nesneler arasında bir bağ... } \\
\text { İnsanla dili arasında bir bağ... } \\
\text { İnsanla vatanı arasında bir } \\
\text { bağ... İnsanla dünya arasında } \\
\text { bir bağ... Birçok bilgin ve } \\
\text { derviş insanlara bu bağ1 } \\
\text { anlatt. Hacı Bektâş-1 Velî, } \\
\text { Mevlânâ, Sarı Saltuk, Geyikli } \\
\text { Baba gibi birçok bilgin ve } \\
\text { derviş... İnsanlar, o bağ ile } \\
\text { yani aşk ile daha güzel oldu. } \\
\text { Yeryüzü, aşkla daha güzel } \\
\text { oldu. }\end{array}$ & $\begin{array}{l}\text { Aşk "bağ"dır. İnsanla Tanrı } \\
\text { arasında bir bağ... İnsanla } \\
\text { insan arasında bir bağ... } \\
\text { İnsanla bütün canliar } \\
\text { arasında bir bağ... İnsanla } \\
\text { nesneler arasında bir bağ... } \\
\text { İnsanla dili arasında bir bağ... } \\
\text { İnsanla vatanı arasında bir } \\
\text { bağ... İnsanla dünya arasında } \\
\text { bir bağ... Birçok bilgin ve } \\
\text { derviş insanlara bu bağ1 } \\
\text { anlattı. Hacı Bektâş-1 Velî, } \\
\text { Mevlânâ, Sarı Saltuk, Geyikli } \\
\text { Baba gibi birçok bilgin ve } \\
\text { derviş... İnsanlar, o bağ ile } \\
\text { birbirlerine daha sik1 } \\
\text { bağlandılar. Yeryüzü, aşk ile } \\
\text { daha da güzelleşti. }\end{array}$ & $\begin{array}{l}\text { Aşk "bağ"dır. İnsanla Tanrı } \\
\text { arasında, insanla insan } \\
\text { arasında ve insanla eşya } \\
\text { arasında bir bağ... İnsanla dili } \\
\text { arasında bir bağ... İnsanla } \\
\text { vatanı arasında bir bağ... } \\
\text { İnsanla dünya arasında bir } \\
\text { bağ... Gelen âşı da giden } \\
\text { derviş de insanlara bu bağ1 } \\
\text { anlattı. Hacı Bektâş-1 Velî, } \\
\text { Mevlânâ, Sarı Saltuk, Geyikli } \\
\text { Baba ve daha niceleri... } \\
\text { İnsanlar, o bağ ile daha da } \\
\text { kenetlendi. Yeryüzü, aşk ile } \\
\text { daha da güzelleşti. Esas } \\
\text { ilkemiz şudur: Yaratılanı sev, } \\
\text { Yaratan'dan ötürü. }\end{array}$ \\
\hline
\end{tabular}


Arka kapakta yer alan paragraflar incelendiğinde temel düzey için 74, orta düzey için 73 ve ileri düzey için 70 kelime kullanılarak "aşk"1n ne olduğunun açıklandığ 1 görülmektedir. Temel düzey öğreniciler için hazırlanan metinde basit cümlelerin kullanılması ve anlatımın daha açık olması gerekliliği kelime sayısının fazla olmasına neden olmaktadır. İleri düzey için hazırlanan paragrafta daha az kelime kullanılmasına rağmen temel ve orta düzeyde yer almayan ek cümlelere yer verilmiştir.

2020 yılı Ağustos ayında 1. baskısı Ankara'da gerçekleştirilen yardımcı okuma kitaplarının imtiyaz sahibi Yunus Emre Enstitüsü Yönetim Kurulu Başkanı Şeref Ateș, editörü ise Prof. Dr. Yavuz Kartallığlu'dur. Yardımcı okuma setine ait diğer künye bilgileri şu şekildedir:

Tablo 2. Türkçenin Sesi Yunus Emre Seti künye bilgileri

\begin{tabular}{ll}
\hline Hikâye & Emine ALTINKAYNAK \\
\hline İnceleme & $\begin{array}{l}\text { Prof. Dr. Gülsün Leyla UZUN } \\
\text { Prof. Dr. Mustafa KURT }\end{array}$ \\
\hline Düzenleme & Betül GÖKTAŞ \\
\hline İllüstrasyonlar-Tasarım & Taha Berk KONAK \\
\hline Dizgi & Mehmet Selim ÖZBAN \\
\hline Basım & Emsal Matbaa Tanıtım Hiz. San. ve Tic. Ltd. Şti. \\
\hline Satış ve Dağıtım & Yunus Emre Enstitüsü \\
\hline ISBN & $978-605-2097-62-5$ (A1-A2) \\
& $978-605-2097-63-2$ (B1-B2) \\
& $978-605-2097-64-9$ (C1-C2) \\
\hline
\end{tabular}

Yardımcı okuma kitaplarında künye bilgilerinden sonra "Sunuş" yer almaktadır. Bu bölümde Yunus Emre Enstitüsünün dünyanın farklı coğrafyalarında gerçekleştirdiği faaliyetlere yer verilmiş, yardımcı okuma kitaplarının hazırlanma amacına değinilmiş ve "Türkçenin Sesi Yunus Emre" setine ait açıklamalarda bulunulmuştur. Sunuş bölümü yardımcı okuma kitaplarının öğrenicilere, dil öğreticilerine ve alan uzmanlarına faydalı olması temennisiyle tamamlanmıştır.

Yardımcı okuma kitaplarının hikâye bölümünde toplam üç illüstrasyon bulunmaktadır. $\mathrm{Bu}$ illüstrasyonlar sırası ile karanfil, balta ve kesilmiş odunlar, şamdan ve mum görsellerinden oluşmaktadır. Karanfil görselinin yer aldığı illüstrasyonda Yunus Emre'ye ait bir şiirin adı olan "Gelin Tanış Olalım" cümlesine yer verilmiştir.

Karanfil, Türk tarihinde süsleme motifi olarak da kullanılan önemli bir çiçektir. Bilinen ilk örneklerine Selçuklu Dönemi taş ve çini işlerinde rastlanmaktadır (Ayvazoğlu, 2013, s. 189). 1240-1320 yılları arasında yaşayan Yunus Emre'nin hayatı, Anadolu Selçuklu Devleti'nin Anadolu topraklarında kalıcı olma mücadelesi verdiği bir döneme karşılık gelmektedir (Tavukçu, 2017, s. 15). Bu bağlamda Selçuklu Dönemi'nde sıklıkla süsleme motifi olarak kullanılan "karanfil"'in Yunus Emre'nin hayatını anlatan bu kitapta illüstrasyon olarak kullanılması çok anlamlıdır.

Yunus Emre Enstitüsünün adının "Yunus Emre" olması bir tesadüf değildir. Yunus Emre hem şiirleriyle Türkçenin gelişimine katkı sağlamış hem de evrensel insani değerler üzerine inşa ettiği hayat felsefesi ile hiçbir din, dil, ırk ayrımı gözetmeksizin insanoğlunun barış içerisinde ve ortak değerler etrafında birlikte yaşamasını amaçlayan mesajlar vermiştir (Yunus Emre Enstitüsü, 2020b). Enstitü de dünya genelinde yürüttüğü Türk dilini ve kültürünü tanıtıcı faaliyetleri ile dünya barışına destek olmayı, farklı milletleri kardeşlik ve dostluk çerçevesi etrafında toplamayı amaçlamakta, bu yolda Yunus Emre'nin “Gelin tanış olalım.” sözünü kardeşliğin bir nişanı olarak kullanmaktadır. Bu nedenle karanfil illüstrasyonunda bu söze yer verildiği düşünülmektedir. 
Kitapta yer alan balta ve düzgün kesilmiş odunlar illüstrasyonu Yunus Emre'nin Tapduk Emre'nin dergâhındaki görevine ve taşıdığı odunlara, şamdan ve mum illüstrasyonu ise kitabın kahramanı olan adamın gecenin karanlığını aydınlatmak için kullandığı şamdan ve muma işaret etmektedir.

Yabancı dil öğretimi için hazırlanan yardımcı okuma kitapları genellikle farklı hikâyelerden oluşan setler şeklinde hazırlanmaktadır. "Türkçenin Sesi Yunus Emre" setinde ise diğerlerinden farklı olarak aynı hikâyenin üç farklı düzey için uyarlanıp etkinliklerle birlikte ögrenicilere sunulduğu görülmektedir. Burada Türk kültürünün en önemli temsilcilerinden olan Yunus Emre'nin hayatının ve hayat felsefesinin bu çalışma aracılığıyla Türkçe öğrenmek isteyen yabancılara tanıtılması amacının güdüldüğü görülmektedir.

Her üç kitapta da özetle uzun süre izin kullanmayan, yoğun bir çalışma temposuna sahip olan ve bu süreçte çok yıpranan bir adamın hikâyesi anlatılmaktadır. İki yılın sonunda iş yerinden izin alabilen kahraman yanına yalnızca yiyecek bir şeyler ve okuyacak kitaplar alarak şehirden uzaktaki dağ evine gider. Amacı şehrin koşturmacasından uzaklaşmak, kendisi ile baş başa kalıp dinlenmek ve kitap okumaktır. Dağ evine ulaşan kahraman, eline Yunus Emre'nin Dîvân'ını alır ve okumaya başlar. Sobanın sıcaklığı ile çok geçmeden uykuya dalan kahraman dışarıdan gelen seslerle gözlerini açar ve kapıyı açıp baktığında uzaklarda genç ve zayıf bir adamın kendisine bakmakta olduğunu fark eder. Gelen Yunus'tur. Kahraman ile Yunus Emre arasında geçen uzun sohbetin ardından kahraman birden uyanır. Yaşadıkları bir rüyadan daha fazlasıdır. Kalan günlerde de Yunus Emre'nin eserlerini okur ve onu anlamaya çalışır. Son gün dağ evinden ayrılmak üzere kapıya çıktı̆̆ında karların üzerinde gördüğü buğday taneleri ise onun nasibidir. Hepsini yerden toplar, bir avuç buğdayla içeri girer ve dudaklarından şu cümleler dökülür: "Aşs olsun, Yunus! Aşk olsun!"

"Türkçenin Sesi Yunus Emre" yardımcı okuma kitaplarında Yunus Emre'nin hayatını ve yaşam felsefesini yazar Emine Altınkaynak'ın çok güçlü bir kurgu ile kaleme aldığ görülmektedir. Hikâye temel, orta ve ileri düzey için üç farklı uyarlamaya sahiptir. Hikâye temel düzeyde 2.177 kelime, orta düzeyde 2.223 kelime ve ileri düzeyde 2.300 kelime ile kurgulanmıştır. Burada düzeyler arttıkça kelime sayısının da arttığı görülmektedir. Bununla birlikte hikâye metinleri incelendiğinde temel düzeyde basit cümlelere ve temel düzey dil bilgisi yapılarına göre cümleler kullanılırken ileri düzeyde üst seviye dil bilgisi yapılarına yer verildiği, birleşik, sıralı ve bağlı cümlelerden yararlanıldığg görülmektedir.

\section{2. "Türkçenin Sesi Yunus Emre” Kitaplarının Etkinlikler Yönünden İncelenmesi}

"Türkçenin Sesi Yunus Emre" yardımcı okuma kitaplarında hikâyenin ardından “etkinlikler" ve "cevaplar" bölümleri gelmektedir. Kitaplarda hikâyeyi okuyan öğrenicilerin daha sonra etkinlikleri tamamlaması ve dil becerilerini geliştirmesi hedeflenmektedir. Etkinlikler bölümünde sırası ile söz varlığı, okuma-anlama, dil bilgisi, yazma ve konuşma başlıklarına yer verilmiş, dinleme becerisi için herhangi bir etkinlik tasarlanmamıştır. Kitaplar incelendiğinde söz varlı̆̆ , okuma-anlama, dil bilgisi, yazma ve konuşma için farklı türlerde etkinlikler hazırlandığı görülmektedir.

Okuma, yazma ve konuşma becerileri ile söz varlığı ve dil bilgisi yeterliklerine ilişkin hazırlanan etkinlik türleri şu şekildedir: 
Tablo 3. Becerilere göre etkinlik türleri

\begin{tabular}{|c|c|c|c|c|c|}
\hline$\frac{\bar{\Xi}}{\bar{I}}$ & Söz Varlığ1 & Okuma-Anlama & Dil Bilgisi & Yazma & Konuşma \\
\hline 1. & $\begin{array}{c}\text { Boşluk } \\
\text { doldurma } \\
\text { (Temel, Orta, } \\
\text { İleri) }\end{array}$ & $\begin{array}{c}\text { Eşleştirme } \\
\text { (Temel, Orta) } \\
\text { Açık uçlu soru } \\
\text { (İleri) }\end{array}$ & $\begin{array}{l}\text { Uygun kelimeyi } \\
\text { seçme (Temel, } \\
\text { Orta, İleri) }\end{array}$ & $\begin{array}{c}\text { Cümle kurma } \\
\text { (Temel, Orta) } \\
\text { Yeniden yazma } \\
\text { (İleri) }\end{array}$ & $\begin{array}{c}\text { Açık uçlu } \\
\text { soru (Temel, } \\
\text { Orta, İleri) }\end{array}$ \\
\hline 2. & $\begin{array}{c}\text { Çoktan seçmeli } \\
\text { soru (Temel, } \\
\text { Orta) } \\
\text { Eşleştirme } \\
\text { (İleri) } \\
\end{array}$ & $\begin{array}{c}\text { Aç1k uçlu soru } \\
\text { (Temel, Orta) } \\
\text { Doğru/yanlış } \\
\text { (İleri) }\end{array}$ & $\begin{array}{l}\text { Boşluk doldurma } \\
\text { (Temel, Orta, } \\
\text { İleri) }\end{array}$ & $\begin{array}{l}\text { Açık uçlu soru } \\
\text { (Temel, Orta) } \\
\text { Metni } \\
\text { tamamlama } \\
\text { (Ileri) } \\
\end{array}$ & $\begin{array}{c}\text { Metinden } \\
\text { hareketle } \\
\text { tartışma } \\
\text { (Orta) }\end{array}$ \\
\hline 3. & $\begin{array}{l}\text { Sözcük bulma } \\
\text { (Temel, Orta, } \\
\text { İleri) }\end{array}$ & $\begin{array}{l}\text { Doğru/yanlış } \\
\text { (Temel, Orta) } \\
\text { Cümleleri sıraya } \\
\text { koyma (İleri) }\end{array}$ & $\begin{array}{c}\text { Çoktan seçmeli } \\
\text { soru (Temel, Orta, } \\
\text { İleri) }\end{array}$ & $\begin{array}{c}\text { Metni } \\
\text { tamamlama } \\
\text { (Temel, Orta) }\end{array}$ & \\
\hline 4. & $\begin{array}{c}\text { Eş anlamlısinı } \\
\text { bulma (Temel, } \\
\text { Orta, İleri) }\end{array}$ & $\begin{array}{l}\text { Cümleleri sıraya } \\
\text { koyma (Temel, } \\
\text { Orta) } \\
\text { Çoktan seçmeli } \\
\text { soru (Ileri) }\end{array}$ & & & \\
\hline 5. & & $\begin{array}{l}\text { Çoktan seçmeli } \\
\text { soru (Temel, } \\
\text { Orta) }\end{array}$ & & & \\
\hline
\end{tabular}

Etkinlik türleri incelendiğinde boşluk doldurma, çoktan seçmeli soru, sözcük bulma, eş anlamlısını bulma, eşleştirme, açık uçlu soru, doğru/yanlış, cümleleri sıraya koyma, uygun kelimeyi seçme, cümle kurma, metni tamamlama ve metinden hareketle tartışma olmak üzere on iki farklı türde etkinlik tasarlandığı görülmektedir. Temel ve orta düzey için hazırlanan etkinlik türleri aynı olmakla birlikte orta düzeyde temel düzeyden farklı olarak "metinden hareketle tartışma" ortamı yaratma üzerine kurgulanmış fazladan bir konuşma etkinliği vardır.

İleri düzey söz varlığı etkinliklerinde çoktan seçmeli soru yerine eşleştirme bulunmaktadır. Okuma anlama etkinliklerinde eşleştirmeye yer verilmemiş; açık uçlu soru, doğru/yanlış, cümleleri sıraya koyma ve çoktan seçmeli soru türleri ile bölüm tamamlanmıştır. İleri düzey dil bilgisi etkinlikleri temel ve orta düzey ile aynı kalırken yazma etkinliklerinde temel ve orta düzeyden farklı olarak yeniden yazma etkinliğine yer verilmiş, açık uçlu sorular sorulmamıştır.

Farklı düzeyler için hazırlanan etkinlik türlerinde ortaklıklar bulunsa da etkinlikler için hazırlanan sorularda öğrenici düzeylerine dikkat edildiği, kullanılan kelimelerin öğrenicilerin muhtemel söz varlıklarına uygun olarak seçildiği, yine soru ve cevapların yazımında düzeye uygun dil bilgisi yapılarının kullanıldığg görülmektedir.

\section{Sonuç ve Öneriler}

Araştırma kapsamında incelenen "Türkçenin Sesi Yunus Emre" seti, hem yabancılara Türkçe öğretimi için hazırlanan yardımcı kaynak olması hem de Türk kültürünün önemli şahsiyetlerinden biri olan Yunus Emre'yi anlatması açısından önem arz etmektedir. Bu tür yardımcı kaynaklar sınıf içi ve sınıf dışı ortamlarda kullanılmaları durumunda dil öğretim süreçlerine katkı sağlayacak, öğrenicilerin öğrenme motivasyonlarını yükseltecek, öğreniciler eğlenerek öğrenecek ve öğrenilenler akılda kalıcı olacaktır. 
Yabancı dil olarak Türkçe öğrenen yetişkinlerin yardımcı okuma kitabı ihtiyacını karşılamak amacıyla hazırlanan "Türkçenin Sesi Yunus Emre" seti incelendiğinde hikâyenin ve hazırlanan illüstrasyonların birbirine uyumlu olacak şekilde seçildiği, görsellerin hem Türk tarihine hem de Yunus Emre'nin hayatındaki önemli noktalara gönderme yaptığı görülmektedir. Hikâyelerde Yunus'un "dosdoğru olma" düşüncesi ve "aşk1 bulma" yolculuğu etkileyici ve anlaşılır bir şekilde öğrenicilere sunulmaktadır. Temel, orta ve ileri düzey için ayrı ayrı kurgulanan hikâyelerde öğrenici düzeyine göre kelime sayıları ve dil bilgisi yapıları değişmektedir. Düzey arttıkça hikâyede daha fazla ayrıntıya yer verilmesi nedeniyle kelime sayıları da artmaktadır. Temel düzeyde hikâye basit cümleler ile verilirken orta ve ileri düzeyde kademeli bir şekilde birleşik, sıralı ve bağlı cümlelere geçildiği görülmektedir.

"Türkçenin Sesi Yunus Emre" yardımcı okuma kitaplarının temel amacı öğrenicilerin okuma becerilerini geliştirmektir. Fakat hazırlanan etkinlikler incelendiğinde kitaplar ile aynı zamanda öğrencilerin söz varlıklarının zenginleştirilmesinin; konuşma, yazma ve dil bilgisi yeterliklerinin geliştirilmesinin hedeflendiği görülmüştür. Kitaplarda dinleme becerisinin geliştirilmesine yönelik etkinlikler bulunmamaktadır. İngilizcenin yabancı dil olarak öğretimi için hazırlanan yardımcı okuma kitapları incelendiğinde o setlerde genellikle ses kaydı olan CD’lere yer verildiği ve öğrencilerin dinleme becerilerinin geliştirilmesine yönelik etkinliklerin hazırlandığ 1 görülmüştür. Bu bağlamda bu set için de sonraki süreçte dinleme etkinliklerinin tasarlanması ve sete dâhil edilmesi yerinde bir gelişme olacaktır.

Yunus Emre'nin hayatını anlatan "Türkçenin Sesi Yunus Emre" yardımcı okuma kitapları sayesinde Türkçe öğrenen yabanc1 öğrenicilerin "Yunus Emre'nin hayatı ve yaşam felsefesi" hakkında bir farkındalık kazanacağı düşünülmektedir. Bununla birlikte öğreticilerin derslerinde, dil düzeylerini dikkate alarak Yunus Emre'nin şiirlerinden de yararlanması gerekmektedir. Yunus Emre şiirlerini basit ve anlaş1lır bir Türkçe ile kaleme almıştır. Bu nedenle Türkçe öğrenen yabancı öğrenicilerin şiirleri anlaması çok zor olmayacaktır. Gemalmaz (1991, s. 61) da Yunus Emre'nin şiirlerinin, günümüzden altı yüz yıl önce yazılmalarına rağmen genel itibarıyla sade ve anlaşılır bir dil ile yazıldığını belirtmekte, şiirlerinin bu derece ilgi görmesinde ve okunmasında şiir dilinin tabii olmasının da etkisi olması gerektiğini ifade etmektedir.

Araştırma kapsamında elde edilen verilerden hareketle hazırlanan öneriler şu şekildedir:

- Yabancılara Türkçe öğretiminde yardımcı kaynaklardan yararlanılmalı, tekdüze ders işlemekten kaçınılmalıdır.

- Öğreticiler süreçte Türk kültürüne ait gelenek, görenek ve şahsiyetlere yer vermelidir.

- Türk kültürünün sembol şahsiyetlerinin hayatları ve eserlerinden hareketle "Türkçenin Sesi Yunus Emre" seti benzeri yardımcı kaynaklar hazırlanmalıdır.

- Öğrencilerin kültürlerine ait gelenek, görenek ve şahsiyetlere saygı duyulmalı, onların hassasiyetlerine önem verilmelidir.

- Alanda çalışacaklar, yardımcı kaynak kullanımı ve kültürel etkileşim konularında farkındalığa sahip öğreticiler olarak yetiştirilmeli, kendilerini sürekli olarak geliştirmelidir.

- Yabancılara Türkçe öğretimi alanını besleyen Türkçe öğretmenliği, Türk dili ve edebiyatı ögretmenliği, Türk dili ve edebiyatı bölümü, çağdaş Türk lehçeleri gibi lisans programlarına ve yabancılara Türkçe öğretimi sertifika programlarına dil öğretiminde kültür etkileşim ile ilgili dersler eklenmelidir.

- Türk kültürüne ait şahsiyet, eser, gelenek ve göreneklerin hangi düzeyde nasıl kullanılabileceği ortaya konmalı; somut bir çerçeve çizilmelidir. 


\section{Kaynakça}

Acartürk, G. (2019). Illüstrasyonda görsel göstergelerin anlatılmast ve mesaj: Gürbüz Doğan Ekşioğlu (Yayımlanmamış yüksek lisans tezi). Ordu Üniversitesi, Ordu.

Alyılmaz, C. ve Er, O. (2016). Yabancılara Türkçe öğretimi uygulamalarında öğretmenlerin kültürel farkındalık oluşturmadaki etkisinin değerlendirilmesi. Uluslararası Türkçe Edebiyat Kültür Ĕ̈itim Dergisi, 5(3), 1392-1413.

Ayvazoğlu, B. (2013). Güller kitabı. İstanbul: Kapı Yayınları.

Bursa Uludağ Üniversitesi (2021). Türkçenin yabancı dil olarak ögretiminde kültür aktarımı. http://bilgipaketi.uludag.edu.tr/Ders/Index/1130715 (Erişim tarihi: 13.08.2021).

Çangal, Ö. (2012). Yabancılara Türkçe öğretiminde kültür taşıyıcısı olarak türküler. Gazi Üniversitesi Türkçe Araştırmaları Akademik Öğrenci Dergisi, 2(2), 9-20.

Çelik, H. (2018). Yabancı dil olarak Türkçe öğretiminde kültürel ihtiyaç analizi (Yayımlanmamış yüksek lisans tezi). Hacettepe Üniversitesi, Ankara.

Elbir, B. ve Aka, F. N. (2015). Yabancılara Türkçe öğretiminde kültür aktarımına yönelik yapılan çalışmaların değerlendirilmesi. International Periodical for the Languages, Literature and History of Turkish or Turkic, 10(12), 371-386.

Gemalmaz, E. (1991). Yunus Emre’nin şiirlerindeki dil özellikleri. Yunus Emre Sempozyumu Bildirileri, Erzurum.

Güleç, İ. ve Ömeroğlu, E. (2020). Yabancılara Türkçe öğretiminde kültür etkileşimi. Ankara: Nobel Yayınevi.

İşcan, A. (2017). Yabancı dil olarak Türkçe öğretiminde kültür aktarım aracı olarak filmlerden yararlanma. Atatürk Üniversitesi Türkiyat Araştırmaları Enstitüsü Dergisi (TAED), 58, 437452.

Kalfa, M. (2013). Yabancılara Türkçe öğretiminde sözlü kültür unsurlarının kullanımı. Millı̂ Folklor, 25(97), 167-177.

Kartallığlu, Y. (Ed.). (2020a). Türkçenin Sesi Yunus Emre (A1-A2). Ankara: Yunus Emre Enstitüsü.

Kartallıŏlu, Y. (Ed.). (2020b). Türkçenin Sesi Yunus Emre (B1-B2). Ankara: Yunus Emre Enstitüsü.

Kartallığlu, Y. (Ed.). (2020c). Türkçenin Sesi Yunus Emre (C1-C2). Ankara: Yunus Emre Enstitüsü.

Memiş, M. R. (2016). Yabancı dil öğretiminde eğitim ortamı ve kültür aktarımı. International Periodical for the Languages, Literature and History of Turkish or Turkic, 11(9), 605-616.

Moralı, G. ve Göçer, A. (2019). Yabancı dil olarak Türkçe öğretiminde kültür paylaşımına yönelik öğretmen görüşleri. Ana Dili Eğitimi Dergisi, 7(4), 1115-1129.

Okur, A. ve Keskin, F. (2013). Yabancılara Türkçe öğretiminde kültürel ögelerin aktarımı: İstanbul Yabancılar için Türkçe Öğretim Seti Örneği. International Journal of Social Science, 6(2), 1619-1640.

Tavukçu, O. K. (Ed.). (2017). Yûnus Emre Kitabı. Ankara: Akçağ Yayınevi.

Türk Dil Kurumu (2019). Yabancılara Türkçe öğretiminde kültür aktarımı çalıştayı Aydın'da yapıldl. https://www.tdk.gov.tr/icerik/basindan/yabancilara-turkce-ogretiminde-kulturaktarimi-calistayi-aydinda-yapildi/ (Erişim tarihi: 26.08.2021). 
Türk, H. (2018). Yabancılara Türkçe ögrretiminde bir izlence tasarımı ve kültürel ögelerin hikâye kitapları aracılı̆̆ıyla aktarımı (Yayımlanmamış yüksek lisans tezi). İhsan Doğramacı Bilkent Üniversitesi, Ankara.

Yıldırım, A. ve Şimşek, H. (2000). Sosyal bilimlerde nitel araştırma yöntemleri. Ankara: Seçkin Yayıncilik.

Y1lmaz, F. ve Akkaya, Ü. (2018). Yabancı dil olarak Türkçe öğretiminde kültür aktarım aracı olarak reklamlar. Route Educational and Social Science Journal, 5(12), 41-52.

Yunus Emre Enstitüsü (2017). Türk kültürüyle tanışın. https://www.yee.org.tr/tr/faaliyet/turkkulturuyle-tanisin (Erişim tarihi: 10.08.2021).

Yunus Emre Enstitüsü (2020a). Türkçenin Sesi Yunus Emre Hikâyeleri (A1-A2). https://www.yee.org.tr/tr/yayin/turkcenin-sesi-yunus-emre-hikayeleri-a1-a2 (Erişim tarihi: 14.08.2021).

Yunus Emre Enstitüsü (2020b). Neden Yunus Emre. https://www.yee.org.tr/tr/kurumsal/nedenyunus-emre (Erişim tarihi: 18.08.2021).

ETIKK ve BİLIMSEL İLKELER SORUMLULUK BEYANI

$\mathrm{Bu}$ çalışmanın tüm hazırlanma süreçlerinde etik kurallara ve bilimsel atıf gösterme ilkelerine riayet edildiğini yazar(lar) beyan eder. Aksi bir durumun tespiti halinde Afyon Kocatepe Üniversitesi Sosyal Bilimler Dergisi'nin hiçbir sorumluluğu olmayıp, tüm sorumluluk makale yazarlarına aittir.

\section{ARAŞTIRMACILARIN MAKALEYE KATKI ORANI BEYANI}

1. yazar katkı oranı : $\% 100$ 